\title{
UPAYA PENCEGAHAN INFEKSI SALURAN KEMIH OLEH PERAWAT PADA PASIEN TERPASANGNYA KATETER DI RUMAH SAKIT UMUM IMELDA PEKERJA INDONESIA MEDAN
}

\author{
Edisyah Putra Ritonga \\ Dosen Prodi S1Keperawatan, STIKes Imelda, Jalan Bilal Nomor 52 Medan \\ E-mail: ediritonga87@gmail.com
}

\begin{abstract}
ABSTRAK
Infeksi saluaran kemih merupakan penyakit yang paling banyak ditemukan di tempat pelanyanan kesehatan. Sebagian besar infeksi saluran kemih disebabkan oleh bakteri tetapi virus dan jamur juga dapat menjadi penyebabnya. Infeksi bakteri sering diakibatkan Escherichia coli. Tujuan penelitian ini adalah mengetahui upanya pencengahan infeksi saluran kemih oleh perawat pada pasien terpasangnya kateter di RSU Imelda Pekerja Indonesia Medan. Jenis penelitan ini adalah penelitian kuantitatif dengan desain deskritif observasioanal dan jumlah sampel dalam penelitian ini adalah 39 orang. Berdasarakan penelitian yang telah dilakukan bahwa mayoritas jenis kelamin responden adalah perempuan yaitu sebanyak 26 responden (66,7\%) dan minoritas jenis kelamin responden adalah laki-laki yaitu sebayak 13 responden (33,3\%). Mayoritas umur responden adalah berumur 20-24 tahun yaitu sebanyak 18 responden (46,2\%) dan minoritas umur responden adalah berumur $>36$ tahun yaitu sebayak 4 responden (10,2\%), mayoritas lama bekerja responden adalah 0-4 tahun yaitu sebanyak 29 responden (74,4\%) dan minoritas lama bekerja responden adalah >10 tahun yaitu sebayak 4 responden (10,3\%). Mayoritas pendidikan responden adalah D-III yaitu sebanyak 33 responden (84,7\%) dan minoritas pendidikan responden adalah S-I Keperawatan yaitu sebayak 6 responden (15,3\%). Berdasarkan dari hasil penelitian yang telah dilakukan dengan memberikan quisioner kepada perawat ditemukan bahwa mayoritas upaya pencegahan infeksi saluran kemih yang dilakukan oleh perawat pada pasien terpasang kateter adalah baik yaitu sebanyak 29 responden (74,3\%) dan minoritas upaya pencegahan infeksi saluran kemih yang dilakukan adalah kurang baik yaitu sebanyak 10 responden (25,7\%). Bagi pihak Rumah Sakit Umum Imelda Pekerja Indonesia Medan diharapkan agar lebih meningkatkan kepatuhan dalam melakukan perawatan kateter urine dalam pencegahan infeksi saluran kemih.
\end{abstract}

Kata kunci : Infeksi Saluran Kemih, Kateter

PENDAHULUAN $\quad$ Infeksi saluran kemih (ISK) merupakan

Infeksi saluaran kemih merupakan penyakit yang paling banyak ditemukan di tempat pelanyanan kesehatan. Infeksi saluaran kemih (ISK) adalah infeksi saluran kemih yang disertai dengan kolonisas bakteri di dalam urine (bakteriuria). Bakteriuria merupakan indikator utama infeksi saluran kemih. Keberadaan bakteriuri a yang mejadi indikasi infeksi saluran kemih yaitu pertumbuhan bakteri murni sebanyak 100.00 Colony forming units $(\mathrm{cfu} / \mathrm{mL})$ atau lebih pada perkembangbiakan urine. Penderita yang mengalami bakteriuria terkadang tanpa disertai tanda dan gejala klinis (asimtomatik) atau dapat disertai tanda dan gejala klinis (simtomatik) (Hooton et al, 2010). infeksi dengan keterlibatan bakteri tersering di komunitas dan hampir $10 \%$ orang pernah terkena ISK selama hidupnya. Sekitar 150 juta penduduk di seluruh dunia tiap tahunnya terdiagnosis menderita infeksi saluran kemih. Prevalensinya sangat bervariasi berdasar pada umur dan jenis kelamin, dimana infeksi ini lebih sering terjadi pada wanita dibandingkan dengan pria yang oleh karena perbedaan anatomis antara keduanya (Rajabnia, 2012). Menurut WHO dalam (2013). Infeksi saluran kemih (ISK) adalah penyakit infeksi yang kedua tersering pada tubuh sesudah infeksi saluran pernafasan dan sebanyak 8,3 juta kasus dilaporkan per tahun.

Kejadian infeksi saluran kemih sering terjadi pada pasien yang terpasangnya dower kateter di rumah sakit. Diketahui bahwa 
pemasangan dower kateter merupakan salah satu saranan masuknya agent atau mikroorganisme dalam tubuh. Adapun faktorfaktor yang mempengaruhi infeksi saluran kemih dapat diubah untuk meminimalkan adalah prosedur pemasangan, lama pemasangan dan kaulitas pemasangan kateter (Schaffer, 2000). Penggunaan kateter urin menyebabkan besarnya kejadian infeksi yang menghasilkan komplikasi infeksi dan kematian (Samad, 2013). Upanya penururnan angka bakteriuria pada pasien yang menggunakan kateter urine indwelling telah menjadi isu patient safety yang harus dijtunjukkan pada semua rumah sakit. Salah satunya mengiplementasikan metode praktek yang baik untuk mengurangi kejadian bakteruria (Buchman \& Stinnett, 2011).

Upanya pencengahan infeksi saluran kemih pada pasien pemasangan kateter dengan melakukan perawatan kateter dengan cara membersihkan daerah sekitar kateter yang masuk kedalam orifisium uretra dengan sabun dan saat memandikan atau membersihkan kotoran pasien, hindari penggunaan bedak dan spray pada daerah parineal, jangan menarik kateter saat pembersihan.

\section{METODE}

\section{Jenis penelitian dan desain penelitian}

Jenis penelitan ini adalah penelitian kuantitatif dengan desain deskritif observasioanal yang bertujuan untuk mengetahui upaya pencengahan infeksi saluran kemih pada pasien terpasangnya kateter di Ruang Rawat Inap Rumah sakit umum Imelda pekerja Indonesia Medan.

\section{Populasi dan sampel}

Populasi dalam penelitian ini adalah seluruh perawat yang berada di ruang rawat inap Rumah Sakit Umum Imelda Pekerja Indonesia Medan yang berjumlah 120 orang perawat. Sampel dalam penelitian ini adalah seluruh populasi yang di ambil dengan tehnik random sampling sistematis berkelipatan 3 berjumlah 39 responden.

\section{Analisa data}

Rancangan analisa data hasil penelitian diformulasikan dengan menempuh langkahlangkah sebagai berikut: Editing, Coding, Sorting, Entry Data, dan Cleaning

\section{HASIL}

Setelah dilakukan penelitian upaya pencegahan infeksi saluran kemih oleh perawat pada pasien terpasangya kateter terhadap 39 responden, maka disajikan dalam tabel berikut ini:

Tabel 1. Distribusi Frekuensi Responden Berdasarkan Jenis Kelamin

\begin{tabular}{rrrr}
\hline No & $\begin{array}{c}\text { Jenis } \\
\text { Kelamin }\end{array}$ & $\mathbf{f}$ & $\mathbf{( \% )}$ \\
\hline 1 & Laki-laki & 26 & 66,7 \\
2 & Perempuan & 13 & 33,3 \\
\hline & Total & $\mathbf{3 9}$ & $\mathbf{1 0 0}$
\end{tabular}

Berdasarkan tabel diatas dapat dilihat bahwa mayoritas jenis kelamin responden adalah perempuan yaitu sebanyak 26 responden $(66,7 \%)$ dan minoritas jenis kelamin responden adalah laki-laki yaitu sebayak 13 responden $(33,3 \%)$.

Tabel 2. Distribusi Frekuensi Responden Berdasarkan Umur

\begin{tabular}{cccc}
\hline No & $\begin{array}{c}\text { Umur } \\
\text { (Tahun) }\end{array}$ & $\mathbf{f}$ & $\mathbf{( \% )}$ \\
\hline 1 & $20-24$ & 18 & 46,2 \\
2 & $25-30$ & 11 & 28,3 \\
3 & $31-35$ & 6 & 15,3 \\
4 & $>36$ & 4 & 10,2 \\
\hline & Total & $\mathbf{3 9}$ & $\mathbf{1 0 0}$ \\
\hline
\end{tabular}

Berdasarakan diatas dapat dilihat bahwa mayoritas umur responden adalah berumur 20-24 tahun yaitu sebanyak 18 responden $(46,2 \%)$ dan minoritas umur responden adalah berumur $>36$ tahun yaitu sebayak 4 responden $(10,2 \%)$. 
Tabel 3. Distribusi Frekuensi Responden Berdasarkan Lama Kerja

\begin{tabular}{cccc}
\hline No & Lama Kerja & $\mathbf{f}$ & $\mathbf{( \% )}$ \\
\hline 1 & $0-4$ tahun & 29 & 74,4 \\
2 & $5-9$ tahun & 6 & 15,3 \\
3 & $>10$ tahun & 4 & 10,3 \\
\hline & Total & $\mathbf{3 9}$ & $\mathbf{1 0 0}$
\end{tabular}

Berdasarkan tabel 3 diatas dapat dilihat bahwa mayoritas lama bekerja responden adalah 0-4 tahun yaitu sebanyak 29 responden $(74,4 \%)$ dan minoritas lama bekerja responden adalah $>10$ tahun yaitu sebayak 4 responden $(10,3 \%)$.

Tabel 4. Upaya Pencegahan Infeksi Saluran Kemih

\begin{tabular}{|c|c|c|c|}
\hline No & Pelaksanaan & f & $(\%)$ \\
\hline 1 & Baik & 29 & 74,3 \\
\hline 2 & Kurang Baik & 10 & 25,7 \\
\hline & Total & 39 & 100 \\
\hline
\end{tabular}

Berdasarkan tabel diatas dapat dilihat bahwa mayoritas upaya pencegahan infeksi saluran kemih yang dilakukan adalah baik yaitu sebanyak 29 responden $(74,3 \%)$ dan minoritas upaya pencegahan infeksi saluran kemih yang dilakukan adalah kurang baik yaitu sebanyak 10 responden $(25,7 \%)$.

\section{PEMBAHASAN}

Berdasarakan penelitian yang telah dilakukan bahwa mayoritas jenis kelamin responden adalah perempuan yaitu sebanyak 26 responden $(66,7 \%)$ dan minoritas jenis kelamin responden adalah laki-laki yaitu sebayak 13 responden (33,3\%). Mayoritas umur responden adalah berumur 20-24 tahun yaitu sebanyak 18 responden $(46,2 \%)$ dan minoritas umur responden adalah berumur $>36$ tahun yaitu sebayak 4 responden $(10,2 \%)$, mayoritas lama bekerja responden adalah 0-4 tahun yaitu sebanyak 29 responden $(74,4 \%)$ dan minoritas lama bekerja responden adalah $>10$ tahun yaitu sebayak 4 responden $(10,3 \%)$.

Berdasarkan dari hasil penelitian yang telah dilakukan dengan memberikan quisioner kepada perawat ditemukan bahwa mayoritas upaya pencegahan infeksi saluran kemih yang dilakukan oleh perawat pada pasien terpasang kateter adalah baik yaitu sebanyak 29 responden $(74,3 \%)$ dan minoritas upaya pencegahan infeksi saluran kemih yang dilakukan adalah kurang baik yaitu sebanyak 10 responden $(25,7 \%)$.

Infeksi saluran kemih merupakan jenis infeksi nosokomial yang sering terjadi dirumah sakit, sejumlah $40 \%$ infeksi nosokomial adalah ISK dan $80 \%$ ISK terjadi setelah terpasang kateterisasi, untuk menekan kejadian infeksi nosokomial saluran kemih perlu adanya peningkatan kualitas perawatan kateter dan perineal hygiene. Oleh karena itu diperlukan peran perawat dalam pelaksanaan perineal hygiene pada pasien yang terpasang kateter, terlebih peran perawat sebagai pemberi asuhan keperawatan, edukator dan advokat. Perawat yang bertugas di ruang rawat inap khususnya pada pasien terpasang kateter hendaknya meningkatkan pelayanan keperawatan dengan lebih baik, harus memperhatikan kondisi pasien dan risiko yang dapat ditimbulkan kepada pasien apabila perawat tidak melakukan perawatan kateter dengan baik.

Rumah sakit mengupayakan peningkatan pelayanan kesehatan yang berfokus pada pemenuhan kebutuhan dasar pasien menjadi dasar utama untuk meningkatan kepuasan pasien. Rumah sakit melakukan survey rutin mengenai tingkat kepuasan pasien di semua bangsal untuk mengetahui bentuk pelayanan yang diharapkan pasien yang terpasang kateter khususnya pada pemenuhan kebutuhan personal hygiene. Kualitas perawatan kateter merupakan tingkat pemberian pelayanan keperawatan berupa perawatan kateter sesuai standar operasional perawatan kateter dengan mengacu pada standar pelayanan profesi keperawatan. Perawatan kateter pada pasien-pasien terpasang kateter dower mutlak dilakukan untuk meminimalkan dampak yang tidak diinginkan berupa terjadinya infeksi nosokomial saluran kemih.

Kualitas perawatan kateter didasarkan pada pemberian perawatan kateter yang dilakukan oleh perawat yang meliputi standar 
operasional perawatan kateter dan prosedur pencegahan infeksi saluran kemih. Untuk menilai kedua unsur tersebut, peneliti melakukan observasi pada perawat dalam melakukan perawatan kateter serta mengkaji keadaan pasien yang terpasang kateter setelah dilakukan tindakan perawatan kateter. Observasi dilakukan selama pasien mulai terpasang dower kateter sampai dilepas atau hari kesepuluh. Hal ini dilakukan karena kejadian infeksi nosokomial terjadi setelah pasien dirawat minimal 3x24 jam.

Hasil penelitian yang dilakukan kasmad di RS Roemani didapatkan perbandingan yang cukup mencolok terhadap hubungan antara perbedaan kualitas perawatan kateter dengan dengan angka kejadian infeksi nosokomial saluran kemih. Kualitas yang kurang angka kejadian infeksinya lebih tinggi yaitu sekitar 83,3\% atau dari 6 responden terdapat 5 yang terjadi dan 1 tidak terjadi infeksi saluran kemih. Kualitas cukup sebanyak $26,67 \%$ atau dari 15 responden terdapat 4 yang terjadi infeksi dan 11 tidak terjadi infeksi saluran kemih. Kualitas baik tingkat kejadian infeksinya sebesar 22,22\% atau dari 9 responden hanya ada 2 yang terjadi infeksi dan 7 tidak terjadi infeksi. Secara keseluruhan prosentase kejadian infeksi nosokomial saluran kemih pada tingkat kualitas perawatan kurang adalah $45,5 \%$, cukup $36,4 \%$ dan baik sebesar $18,2 \%$ dari 30 responden.

Pencegahan lain yaqng dapat dilakukan dalam pencegahan infeksi saluran kemih yaitu dengan mencuci tangan adalah prosedur kesehatan yang paling penting yang dapat dilakukan oleh semua orang untuk mencegah penyebaran kuman. Cuci tangan harus selalu dilakukan dengan benar sebelum dan sesudah melakukan tindakan perawatan walaupun memakai sarung tangan atau alat pelindung lain untuk menghilangkan atau mengurangi mikroorgani sme yang ada ditangan sehingga penyebaran penyakit dapat dikurangi dan lingkungan terjaga dari infeksi. Cuci tangan tidak dapat digantikan oleh pemakaian sarung tangan (Nursalam, 2010).
Menurut WHO untuk meningkatkan kepatuhan dalam mencuci tangan bisa mencapai $100 \%$. Hasil penelitian melakukan hand hygiene diperlukan multidimensi strategi oleh Damanik menunjukkan bahwa adanya pengawasan pendekatan. Pendekatan tersebut meliputi perubahan terhadap pelaksanaan hand hygiene lebih banyak patuh sistem dengan menyediakan hand rub berbasis alkohol melakukan hand hygiene. Arifien menunjukkan selain wastafel dan sabun antiseptik di setiap titik bahwa responden yang mendapat dukungan dari perawatan, pendidikan dan pelatihan kepada petugas pimpinannya berpeluang lebih patuh sebesar 21 kali kesehatan secara teratur dan berkala, evaluasi dan umpan dibandingkan dengan responden yang kurang mendapat balik berupa monitoring, evaluasi dan pemberian umpan dukungan dari pimpinanny a.

Selain itu hasil juga balik pelaksanaan dan infra struktur hand hygiene, menunjukkan bahwa ada hubungan yang bermakna antarapersepsi dan pengetahuan petugas kesehatan secara dukungan/komitme $\mathrm{n}$ pimpinan dengan teratur, adanya pengingat di tempat kerja untuk promosi Berdasarkan pengamatan kepatuhan hand hygiene dan meningkatkan kepedulian petugas kesehatan. Upaya perawat ruang rawat inap rumah sakit masih rendah tersebut harus ditunjang dengan dukungan organisasi dan (35\%). Kepatuhan hand hygiene perawat lebih banyak partisipasi pasien untuk meningkatkan budaya dilakukan sesudah perawat melakukan tindakan invasive keselamatan. Hasil penelitian Benedetta et al di Afrika aseptik, dan paling sedikit dilakukan sebelum perawat menunjukkan dengan mengimpleme ntasikan strategi dari kontak dengan pasien. Kunci keberhasilan hand hygiene berasal dari pengetahuan perawat yang kurang, tidak adanya berbagai intervensi yang melibatkan perubahan perilaku, pelaksanaan audit hand hygiene secara berkala yang pendidikan kreatif, monitoring dan evaluasi, dan lebih diketahui perawat, dan tidak ada supervisi kepala ruang penting adalah keterlibatan supervisor sebagai rolemodel terhadap 
pelaksanaan hand hygiene di ruang rawat inap serta dukungan pimpinan.

Menurut asumsi peneliti tingkat pengetahuan perawat dalam pencegahan infeksi saluran kemih sangat berpengaruh terhadap tindakan dalam pencegahan infeksi. Menurut peneliti apabila semakin tinggi pendidikan responden ini akan mempengaruh i pengetahuan responden. Hal ini sesuai dengan teori Notoadmojo (2010) bahwa pengetahuan seseorang dipengaruhi oleh pendidikan seseorang.

\section{KESIMPULAN}

Berdasarkan hasil penelitian yang telah dilakukan terhadap 39 responden, maka diperoleh kesimpulan sebagai berikut:

- Mayoritas jenis kelamin responden adalah perempuan yaitu sebanyak 26 responden $(66,7 \%)$ dan minoritas jenis kelamin responden adalah laki-laki yaitu sebayak 13 responden $(33,3 \%)$.

- Mayoritas umur responden adalah berumur 20-24 tahun yaitu sebanyak 18 responden $(46,2 \%)$ dan minoritas umur responden adalah berumur $>36$ tahun yaitu sebayak 4 responden $(10,2 \%)$,

- Mayoritas lama bekerja responden adalah 0-4 tahun yaitu sebanyak 29 responden $(74,4 \%)$ dan minoritas lama bekerja responden adalah $>10$ tahun yaitu sebayak 4 responden $(10,3 \%)$.

- Mayoritas pendidikan responden adalah D-III yaitu sebanyak 33 responden $(84,7 \%)$ dan minoritas pendidikan responden adalah S-I Keperawatan yaitu sebayak 6 responden $(15,3 \%)$.

- Mayoritas upaya pencegahan infeksi saluran kemih yang dilakukan oleh perawat pada pasien terpasang kateter adalah baik yaitu sebanyak 29 responden $(74,3 \%)$ dan minoritas upaya pencegahan infeksi saluran kemih yang dilakukan adalah kurang baik yaitu sebanyak 10 responden $(25,7 \%)$.

\section{SARAN}

1. Institusi pendidikan keperawatan Hendaknya institusi pendidikan keperaw atan secara terus-

menerus memberikan pengajaran kepada mahasiswa/mahasiswi khususnya tentang pencegahan infeksi dan perawatan kateter urine.

2. Bagi rumah sakit

Bagi pihak Rumah Sakit Umum Imelda Pekerja Indonesia Medan diharapkan agar lebih meningkatkan kepatuhan dalam melakukan perawatan kateter urine dalam pencegahan infeksi saluran kemih.

3. Bagi Responden

Bagi responden diharapkan agar lebih patuh dalam melakukan perawatan kateter urine dan peningkatan pengetahu an tentang prosedur pemasangan kateter.

4. Bagi peneliti selanjutnya

Diharapkan dapat melanjutkan penelitian ini dengan cakupan sampel yang lebih besar serta dapat menggunakan teknik penelitian lain misalnya eksperimental, tidak terbatas hanya deskriptif saja.

\section{DAFTAR PUSTAKA}

a.n, (2010). Pendidikan Dan Perilaku Kesehatan. Jakarta: Rineka Cipta.

Arikunto, Suharsimi. (2007). Prosedur Penelitian Suatu Pendekatan Praktek. Jakarta: Rineka Cipta.

Black, JM \& Hawks, JH. (2009). Medical surgical nursing: clinical management for positive outcomes volume 1. edisi 8 . St. Louis: Elsevier.

Darmadi. (2008). Infeksi Nosokomial; Problematika dan Pengendaliannya. Jakarta: Salemba Medika.

Departemen Kesehatan Republik Indonesia (DepKes RI). (2007). Pedoman Manajerial Pencegahan dan Pengendali an Infeksi di Rumah Sakit Fasilitas Pelayanan Kesehatan Lainnya. Jakarta: Depkes RI.

Hooton, T.M., et al., (2010). Infectious Diseases Society of America. Diagnosis, prevention, and treatment of catheter- 
associated urinary tract infection in adults. International Clinical Practice Guidelines from the Infectious Diseases Society of America. 50(5), 625-63.

Notoatmodjo. (2010). Promosi Kesehatan Dan Ilmu Perilaku. Jakarta: PT Rineka Cipta.

Nursalam, (2008). Konsep Dan Penerapan Metodologi Penelitian Ilmu Keperawata. Jakarta: Salemba Medika.

Potter, PA \& Perry, AG. (2010). Fundament al keperawatan buku 3, edisi 7. Jakarta: Salemba Medika.

Riduan. (2010). Skala Pengukuran Variabelvariabel Penelitian. Bandung: Alfabeta.

Setiadi. (2007). Konsep dan Penulisan Riset Keperawata. Yogyakarta: Graha Ilmu.
World Health Organization. (2009). Hand Hygiene: Why, How \& When?. Hopitaux Universitaires de Geneve (HUG). Diakses $05 \quad$ Maret 2017. http://www.who.int/gpsc/5may/Hand_H ygiene_Why_How_and_When_Brochur e.pdf.

World Health Organization. (2009). WHO Guidelines on Hand Hygiene in Health Care: First Global Patient Safety Challenge Clean Care is Care Safer Care. Diakses 05 Maret 2017. http://app s.who.int/iris/bitstream/handle/10665/44 102/9789241597906_eng.pdf;jsessionid $=$ F2CDC383DB61BFCD94F1C10D78E 89DA7? sequence $=1$.

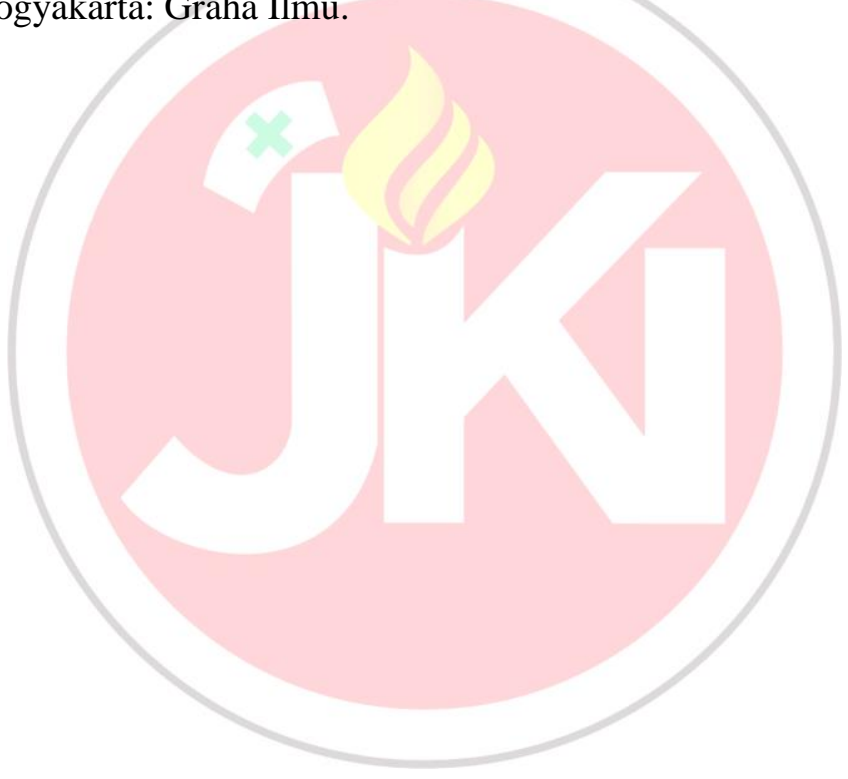

